\title{
Comparative gastrointestinal and plasma cholesterol responses of rats fed on cholesterol-free diets supplemented with guar gum and sodium alginate
}

\author{
C. J. Seal* and J. C. Mathers \\ Human Nutrition Research Centre, Department of Biological and Nutritional Sciences, University of Newcastle, Newcastle \\ upon Tyne, NE1 7RU, UK
}

(Received 7 January 2000 - Revised 10 August 2000 - Accepted 21 September 2000)

\begin{abstract}
The present study investigated the digestion and cholesterol-lowering effects of the watersoluble NSP guar gum (GG) and sodium alginate (SA) in laboratory animals. Groups of five male Wistar strain rats were fed semi-purified cholesterol-free diets containing 0,50 or $100 \mathrm{~g}$ NSP source/kg for $21 \mathrm{~d}$ which comprised a 14-d adaptation period followed by a 7-d balance period. Weight gain over the balance period and food conversion ratio decreased linearly with increasing NSP intake $(P=0.006$ and $P=0.07$ respectively). DM digestibility decreased with increasing NSP intake $(P=0.001)$ and this effect was greater for SA-containing diets compared with GG-containing diets $(P=0.001)$. At the lower inclusion rate, $0.9-1.0$ of the additional NSP was digested, but this value fell to 0.8 for both NSP sources at the $100 \mathrm{~g} / \mathrm{kg}$ inclusion rate, implying that the capacity for near complete digestion of the test NSP had been exceeded. Intestinal tissue mass was increased in response to inclusion of both NSP sources. Caecal digesta $\mathrm{pH}$ decreased linearly with additional GG, but increased slightly with consumption of SA. Total caecal short-chain fatty acid concentrations ( $\mu \mathrm{mol} / \mathrm{g}$ caecal contents) increased markedly with $50 \mathrm{~g} \mathrm{GG} / \mathrm{kg}$ but did not increase further with $100 \mathrm{~g} \mathrm{GG} / \mathrm{kg}$, and were slightly lower than control values in rats consuming SA. Plasma cholesterol concentration fell linearly $(P=0.03)$ with increasing NSP in the diet and the effect was similar for both GG and SA. Total output of faecal bile acids rose in rats fed $50 \mathrm{~g} \mathrm{GG} / \mathrm{kg}$ and $50 \mathrm{~g} \mathrm{SA} / \mathrm{kg}(59 \mu \mathrm{mol} / 7 \mathrm{~d} v .24 \mu \mathrm{mol} / 7 \mathrm{~d}$ for control rats) with no further increase at the higher inclusion rate. These results show that SA has a strong hypocholesterolaemic effect in rats which is similar to that of GG, and that this effect is most likely to be mediated through an interruption in the entero-hepatic circulation of bile acids and not through increased hepatic supply of propionate from fermentation of the NSP in the large bowel.
\end{abstract}

Sodium alginate: Cholesterol metabolism: Bile acids: NSP digestion: Caecal fermentation

Previous studies in man and with laboratory animals have shown that consumption of moderate amounts of soluble dietary NSP may produce beneficial changes in lipid metabolism including lowered fasting blood cholesterol concentrations and alterations in the ratio of HDL-:LDLcholesterol in plasma (Tredger et al. 1991; Frape \& Jones, 1995; Truswell, 1995; Brown et al. 1999). The mechanisms of these effects are not clear, but may include long-term changes in lipid metabolism in response to modified postprandial hormone levels. For example, reduced postprandial plasma insulin concentrations and attenuated gastric inhibitory peptide release as a consequence of delayed glucose and fat absorption may influence the clearance of triacylglycerols and the transfer of cholesterol from HDL to LDL (Morgan et al. 1993; Frape \& Jones, 1995). Other suggested mechanisms for the effects of NSP on fasting plasma cholesterol concentrations include interruption of the entero-hepatic circulation of bile acids leading to increased liver sterol output and faecal bile acid excretion (Story et al. 1997), and influences on the production and absorption of short-chain fatty acids (SCFA), especially propionate in the large bowel (Chen et al. 1984).

Alginates, extracted using acid and alkali from brown

\footnotetext{
Abbreviations: GG, guar gum; $5 \% \mathrm{GG}, 10 \% \mathrm{GG}, 50$ and $100 \mathrm{~g}$ guar gum/kg respectively; SA, sodium alginate; $5 \% \mathrm{SA}, 10 \% \mathrm{SA}, 50$ and $100 \mathrm{~g}$ sodium alginate respectively; SCFA, short-chain fatty acid.

* Corresponding author: Dr C. J. Seal, fax + 44191222 8684, email chris.seal@ncl.ac.uk
} 
seaweed, are widely used in small amounts in foods as gelling agents, thickeners, stabilisers or emulsifiers (Michel $\&$ Macfarlane, 1996). The majority of algal polysaccharides are resistant to mammalian gastrointestinal hydrolases and their digestion is dependent on microbial depolymerisation and fermentation in the large intestine. The main constituents of alginates are uronic acids (1,4- $\beta$-mannuronic acid and 1,4- $\alpha$-guluronic acids (Martin, 1986)), giving the NSP physico-chemical characteristics similar to those of pectin (galacturonic acid). Sodium alginate (SA) is readily water-soluble and produces a highly viscous gel in solution containing partially-ionized carboxyl groups. Alginates have potential for use as a 'functional food', since the production of $\beta$-elimination products by bacterial alginate-degrading enzymes may increase the growth of beneficial Bacteroides species of bacteria in the gut (Michel \& Macfarlane, 1996). Guar gum (GG) produces the highest viscosity of any natural gum (BeMiller \& Whistler, 1996), and is a galactomannan composed of a main chain of 1,4 $\beta$-D-mannopyranosyl with single unit $\alpha$ D-galactopyranosyl branches.

The aim of the present experiment was to investigate the effect of SA on digestion and cholesterol metabolism in the laboratory rat in comparison with GG, a NSP with known hypocholesterolaemic properties. The experiment formed part of a series of studies which compared the physiological and nutritional effects of GG with algal dietary fibres in human volunteers (Roper et al. 1996). Preliminary data from the experiment have been published in abstract form (Seal \& Mathers, 1996).

\section{Materials and methods}

\section{Animals and diets}

Twenty-five male Wistar strain rats, initial average weight $127 \mathrm{~g}$ (SE 1.2), were obtained from the Comparative Biology Centre, University of Newcastle, and housed in individual plastic metabolism cages in a controlledenvironment room in this Centre throughout the study. All procedures were conducted in accordance with Home Office regulations. Rats were randomly allocated to one of five semi-purified cholesterol-free diets containing 0,50 or $100 \mathrm{~g} \mathrm{GG} / \mathrm{kg}$ diet (Control, $5 \% \mathrm{GG}$ and $10 \% \mathrm{GG}$ respectively) or 50 or $100 \mathrm{~g}$ SA $(5 \% \mathrm{SA}$ and $10 \% \mathrm{SA}$ respectively) $/ \mathrm{kg}$ diet. The added NSP sources replaced some of the maize starch in the diets, which otherwise remained of constant composition and were formulated to meet all macro- and micronutrient requirements (Table 1). $\mathrm{Cr}_{2} \mathrm{O}_{3}(2 \mathrm{~g} / \mathrm{kg}$ diet $)$ was included as an indigestible marker. Animals were offered $15 \mathrm{~g}$ air-dry food at 10.00 hours daily and uneaten food was removed the following morning. Water was available ad libitum. The rats were fed the diets for a total of $21 \mathrm{~d}$, which comprised a $14-\mathrm{d}$ adaptation period followed by a 7-d balance period. Food residues were removed each day, dried at $100^{\circ} \mathrm{C}$ and weighed.

\section{Measurements}

Animals were weighed at the beginning and end of the balance period. Complete collections of urine (into flasks
Table 1. Formulation $(\mathrm{g} / \mathrm{kg})$ of experimental diets

\begin{tabular}{|c|c|c|c|c|c|}
\hline Diet... & Control & $5 \%$ GG & $10 \%$ GG & $5 \%$ SA & $10 \% \mathrm{SA}$ \\
\hline \multicolumn{6}{|l|}{ Ingredients } \\
\hline Maize starch & 250 & 200 & 150 & 200 & 150 \\
\hline Sucrose & 288 & 288 & 288 & 288 & 288 \\
\hline Guar gum* & 0 & 50 & 100 & 0 & 0 \\
\hline Sodium alginate† & 0 & 0 & 0 & 50 & 100 \\
\hline Casein & 200 & 200 & 200 & 200 & 200 \\
\hline Groundnut oil & 150 & 150 & 150 & 150 & 150 \\
\hline Celluloseł & 50 & 50 & 50 & 50 & 50 \\
\hline Mineral premix§ & 40 & 40 & 40 & 40 & 40 \\
\hline Vitamin premix & 20 & 20 & 20 & 20 & 20 \\
\hline $\mathrm{Cr}_{2} \mathrm{O}_{3}$ & 2 & 2 & 2 & 2 & 2 \\
\hline \multicolumn{6}{|c|}{ Analysed composition ( $\mathrm{g} / \mathrm{kg}$ as fed) } \\
\hline Total N & 24 & 26 & 26 & 27 & 25 \\
\hline Total NSP & 51 & 91 & 127 & 93 & 138 \\
\hline
\end{tabular}

$5 \%$ GG, $10 \%$ GG, 50 and $100 \mathrm{~g}$ guar gum $/ \mathrm{kg}$ respectively; $5 \%$ SA, $10 \%$ $\mathrm{SA}, 50$ and $100 \mathrm{~g}$ sodium alginate/kg respectively.

* Sigma Chemical Poole, Dorset.

† Provided by CEVA, Pleubian, France.

$\ddagger$ Alphacel (ICN Biomedicals Inc., Aurora, OH, USA)

$\S$ AIN Mineral Mixture 76 (ICN Biomedicals Inc.).

If AIN Vitamin Mixture 76A (ICN Biomedicals Inc.).

containing $5 \mathrm{ml} 0 \cdot 05 \%(\mathrm{v} / \mathrm{v}) \mathrm{H}_{2} \mathrm{SO}_{4}$ ) and faeces were made daily during the balance period. Pooled urine samples from each rat were diluted to $250 \mathrm{ml}$ with double-distilled water and a portion was retained for analysis. Faecal samples were bulked, freeze-dried and milled for analyses. At the end of the balance period gastrointestinal and blood samples were obtained from all rats following terminal anaesthesia by intraperitoneal injection of Hypnorm/Midazolam ( $1 \mathrm{ml} / 300 \mathrm{~g}$ body weight, prepared by the Comparative Biology Centre). Blood samples $(5 \mathrm{ml})$ were collected from the heart into heparinised syringes and cooled on ice. Plasma was separated by centrifugation and stored at $-20^{\circ}$. The entire gastrointestinal tract was removed and the length of the small intestine measured from the pylorus to the ileo-caecal junction. The caecum and colon were separated and weighed, and the $\mathrm{pH}$ of the caecal contents was measured by insertion of a microelectrode connected to a $\mathrm{pH}$ meter. Duplicate portions (approximately $0.5 \mathrm{~g}$ ) of caecal digesta were mixed $(2: 1 \mathrm{w} / \mathrm{v})$ with deproteinising solution $\left(\mathrm{H}_{3} \mathrm{PO}_{3} \quad(20 \mathrm{~g} / \mathrm{l})\right.$ containing $50 \mathrm{mM}-3$-methyl-valeric acid) and stored frozen at $-20^{\circ}$. Caecal and colonic tissue were rinsed free of digesta with physiological saline $(9 \mathrm{~g} \mathrm{NaCl} / \mathrm{l})$ lightly blotted dry and re-weighed.

\section{Analytical and statistical methods}

SCFA in caecal contents were measured by GC as previously described (Mathers et al. 1990). The Cr content of freeze-dried faecal samples was determined by atomic absorption spectrophotometry after ashing and wet digestion with $\mathrm{MgSO}_{4}$ and $\mathrm{KBrO}_{3}$ as previously described (Mathers et al. 1990). The $\mathrm{N}$ content of diluted urine and freeze-dried faecal samples was determined by combustion using a Leco FP428 nitrogen analyser (Leco Instruments (UK) Ltd, Stockport, Cheshire, UK). Plasma total cholesterol concentration was determined enzymically using a commercial kit (Ultimate 2; Roche Diagnostics, Welwyn 
Garden City, Herts) on a Cobas Mira Clinical Analyser (Roche Diagnostics, Welwyn Garden City, Herts). Faecal total bile acids were determined enzymically by means of a commercial kit based on 3 $\alpha$-hydroxysteroid dehydrogenase (Enzabile; Nycomed (UK) Ltd, Birmingham, UK) after methanol extraction from freeze-dried faecal samples as described by Setchell et al. (1983). Total bile acids determined by this method include steroids of the $\mathrm{C}_{19}, \mathrm{C}_{21}$ and $\mathrm{C}_{24}$ series, including taurine and glycine conjugates of the $\mathrm{C}_{24}$ series. Dietary and faecal NSP were analysed colorimetrically after enzymic digestion and acid hydrolysis as described by Englyst \& Cummings (1984).

DM digestibility was calculated using the following formula:

$$
\frac{\text { DM consumed }-\mathrm{DM} \text { in faeces }}{\text { DM consumed }} .
$$

The apparent digestibility of added NSP was calculated using the following formulas:

$$
\begin{aligned}
& \text { NSP intake from test NSP source (A) } \\
& =\text { DM intake on test } \operatorname{diet}(\mathrm{g} / 7 \mathrm{~d}) \\
& \quad \times(\mathrm{NSP} \text { content of test diet } \\
& \quad-\mathrm{NSP} \text { content of control diet }(\mathrm{g} / \mathrm{kgDM})),
\end{aligned}
$$

faecal NSP output from test NSP source (B)

$=$ total NSP output on test diet

- (((DM intake on test diet $(\mathrm{g} / 7 \mathrm{~d}) /$

mean DM intake on control diet))

$\times$ mean NSP output on control diet),

digestibility of added NSP $=(\mathrm{A}-\mathrm{B}) / \mathrm{A}$.
Statistical analysis of the difference between means for each treatment was by ANOVA using the general linear models procedure (Minitab, State College, PA, USA). Treatment sums of squares were subdivided into four $a$ priori orthogonal contrasts: contrast 1, linear (L) effect of added NSP; contrast 2, deviations from linear (D) effect of added NSP; contrast 3, L $\times$ NSP source interaction; and contrast $4, \mathrm{D} \times \mathrm{NSP}$ source interaction. Each contrast was tested against the 'between rats within diets' error term with $18 \mathrm{df}$. Tables of results show mean values with probability values for each contrast. For NSP digestibilities only, data were examined for effects of test NSP sources, dose and source $\times$ dose interaction using a $2 \times 2$ factorial analysis.

\section{Results}

\section{Food intake, rat growth, food conversion ratio and nitrogen balance}

Owing to large food refusals during the adaptation period, two rats from the $10 \% \mathrm{SA}$ diet were removed from the experiment. Food refusals were negligible during the balance period and DM intake was, therefore, similar across all five diets (Table 2). Weight gain during the balance period was greatest for rats consuming the control diet and decreased linearly $(P=0.006)$ with additional $\mathrm{GG}$ and SA. Food conversion ratio ( $\mathrm{g}$ food DM eaten/g live-weight gain) was also lower for GG- and SAcontaining diets and decreased linearly with increasing GG and SA in the diet $(P=0.07$; Table 2). DM digestibility decreased linearly with increasing NSP intake $(P<0.001$; Table 2) with a steeper slope for SAcontaining diets compared with GG-containing diets $(P=0.001$; contrast 3$)$. The slightly higher concentration of $\mathrm{N}$ in GG- and SA-containing diets (Table 1) was reflected in higher $\mathrm{N}$ intakes for animals consuming these diets compared with the control group. Faecal $\mathrm{N}$ output increased linearly $(P<0.001)$ with increasing NSP intake

\begin{tabular}{|c|c|c|c|c|c|c|c|c|c|c|}
\hline \multirow[b]{2}{*}{ Diet... } & \multirow[b]{2}{*}{ Control } & \multirow[b]{2}{*}{$5 \%$ GG } & \multirow[b]{2}{*}{$10 \%$ GG } & \multirow[b]{2}{*}{$5 \%$ SA } & \multirow[b]{2}{*}{$10 \% \mathrm{SA}$} & \multirow[b]{2}{*}{ SEM } & \multicolumn{4}{|c|}{ Statistical significance of contrast $\dagger(P)$ : } \\
\hline & & & & & & & 1 & 2 & 3 & 4 \\
\hline DM intake $(g / 7 d)$ & 100 & 100 & 99 & 98 & 100 & 0.3 & 0.58 & 0.08 & 0.89 & 0.007 \\
\hline Final rat wt (g) & 234 & 227 & 214 & 216 & 210 & 3.0 & 0.006 & 0.79 & 0.68 & $0 \cdot 18$ \\
\hline Wt gain $(g / 7 d)$ & 36 & 31 & 29 & 31 & 27 & 1.5 & 0.07 & 0.69 & 0.70 & $>0.99$ \\
\hline $\begin{array}{l}\text { Food conversion ratio } \\
(\mathrm{g} \text { DM consumed/wt gain }(\mathrm{g}))\end{array}$ & 0.36 & 0.31 & 0.29 & 0.31 & 0.27 & 0.002 & 0.07 & 0.75 & 0.69 & $0 \cdot 89$ \\
\hline Faecal DM output (g/7 d) & 7.9 & $10 \cdot 2$ & 11.4 & $9 \cdot 3$ & $13 \cdot 8$ & 0.42 & $<0.001$ & 0.38 & $<0.001$ & 0.07 \\
\hline DM digestibility & 0.92 & 0.89 & 0.89 & 0.91 & 0.86 & 0.002 & $<0.001$ & 0.51 & 0.001 & 0.15 \\
\hline $\mathrm{N}$ intake $(\mathrm{g} / 7 \mathrm{~d})$ & 2.53 & $2 \cdot 75$ & $2 \cdot 73$ & $2 \cdot 72$ & 2.64 & 0.019 & $<0.001$ & $<0.001$ & 0.001 & 0.17 \\
\hline Faecal $N$ output $(g / 7 d)$ & 0.14 & 0.26 & 0.32 & 0.19 & 0.25 & 0.015 & $<0.001$ & 0.81 & 0.35 & 0.12 \\
\hline Urinary N output ( $g / 7 d)$ & 0.93 & 0.93 & 0.99 & 0.82 & 0.91 & 0.024 & 0.50 & $0 \cdot 18$ & 0.35 & $0 \cdot 12$ \\
\hline $\mathrm{N}$ retention $(\mathrm{g} / 7 \mathrm{~d})$ & 1.46 & 1.56 & 1.42 & 1.72 & 1.48 & 0.030 & 0.37 & $<0.001$ & 0.49 & 0.03 \\
\hline
\end{tabular}
to reach approximately double control levels with the

Table 2. Food DM intake, indigestibility, growth rate and aspects of nitrogen metabolism during balance period in rats given semi-purified diets' supplemented with 50 and $100 \mathrm{~g}$ guar gum $/ \mathrm{kg}$ (5\% GG and $10 \% \mathrm{GG}$ respectively) or 50 and $100 \mathrm{~g}$ sodium alginate/kg (5\% SA and $10 \%$ SA respectively)*

(Means for five rats per diet, except $10 \%$ SA where values are for three rats per diet)

${ }^{*}$ For details of diets and procedures, see Table 1. and p. 318.

† Contrast 1 , linear (L) effect of added NSP; contrast 2, deviations from linear (D) effect of added NSP; contrast $3, \mathrm{~L} \times$ NSP source interaction; contrast 4 , D $\times$ NSP source interaction. 


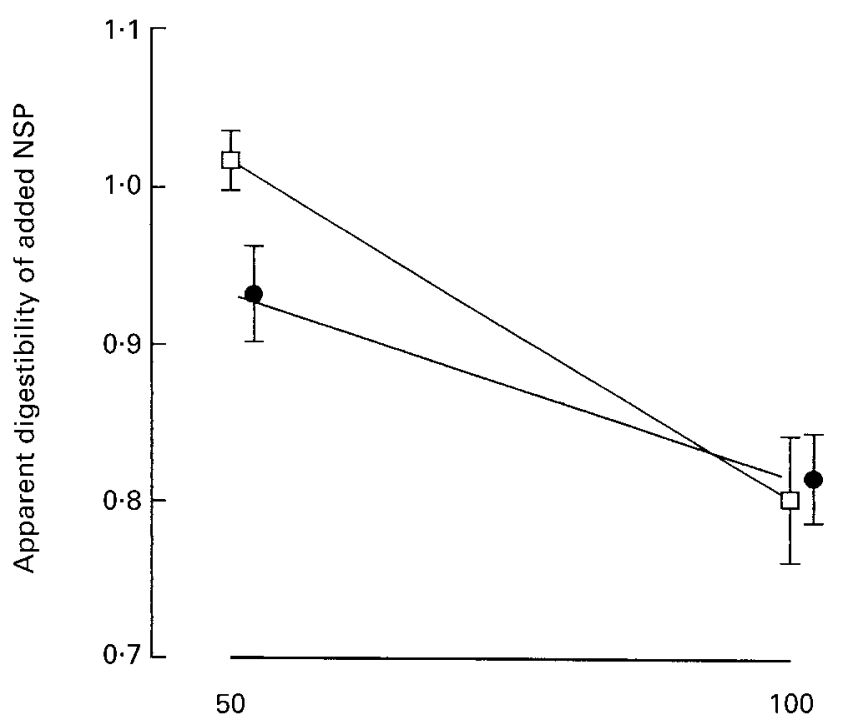

Level of NSP source $(\mathrm{g} / \mathrm{kg}$ diet)

Fig. 1. Mean apparent digestibility of added test NSP sources in rats fed semi-purified diets supplemented with 50 and $100 \mathrm{~g}$ guar gum $/ \mathrm{kg}$ $(\square)$ or 50 and $100 \mathrm{~g}$ sodium alginate/kg $(\bullet)$. For details of diets and procedures, see Table 1 and p. 318. Values are means with their standard errors represented by vertical bars for five rats per diet except $100 \mathrm{~g}$ sodium alginate/kg where there were three rats per diet. The effect of the level of added NSP was significant $(P<$ 0.001 ). For details of calculations see p. 319.

higher dose of NSP. Urinary $\mathrm{N}$ excretion was not significantly influenced by diet but there was a significant deviation from linearity in the effect of added GG and SA $(P<0.001)$ on $\mathrm{N}$ retention, which was highest at the $50 \mathrm{~g} /$ $\mathrm{kg}$ inclusion rate for both NSP sources.

Apparent digestibility of the added test NSP sources is shown in Fig. 1. With $50 \mathrm{~g} \mathrm{GG/kg} \mathrm{diet,} \mathrm{the} \mathrm{added} \mathrm{NSP} \mathrm{was}$ completely digested $(95 \% \mathrm{Cl} 1.08,0.95)$ and approximately 0.93 (95 \% Cl 1.00, 0.87) of the SA was digested in the $5 \%$ SA diet. At the $100 \mathrm{~g} / \mathrm{kg}$ inclusion rate, digestibility of the added NSP fell significantly $(P<0.001)$ to 0.81 $(95 \% \mathrm{Cl} 0.86,0.76)$ for both test NSP sources.
Intestinal tissue mass, caecal $\mathrm{pH}$ and fermentation pattern

Small intestine length of GG- and SA-fed rats increased by approximately $20 \%$ compared with control rats (Table 3). There was a significant linear increase in caecal tissue mass and the mass of caecal digesta in response to inclusion of the NSP sources which was similar for both GG and SA $(P<0.001$; Table 3$)$ in response to inclusion of the NSP. Colonic digesta mass and colonic tissue mass were higher in animals fed GG and SA with similar values for 50 and $100 \mathrm{~g} / \mathrm{kg}$ inclusion rates for both NSP sources.

Caecal digesta $\mathrm{pH}$ fell steadily from 6.6 on the control diet to $6 \cdot 1$ in rats consuming the $10 \% \mathrm{GG}$ diet, but was slightly increased above the value for the control diet by consumption of diets containing SA (Table 4). Total SCFA ( $\mu \mathrm{mol} / \mathrm{g}$ caecal contents) increased markedly with the $5 \% \mathrm{GG}$ diet but did not increase further with the $10 \% \mathrm{GG}$ diet. Total SCFA concentrations in caeca of rats consuming SA were slightly lower than that of control rats and was unaffected by the level of inclusion of SA. Adding $50 \mathrm{~g} \mathrm{GG} /$ $\mathrm{kg}$ diet produced a $60 \%$ increase in caecal butyrate molar proportion, which was balanced by reductions in the molar proportions of all other measured SCFA (Table 4). However, with the higher inclusion rate for $G G$, the proportion of butyrate and other SCFA returned to similar to control values. Consumption of SA-containing diets was associated with a modest increase in the proportion of acetate with compensatory decreases in the molar proportions of propionate and, to a lesser extent, of butyrate. The contributions made by both isobutyrate and valerate to the SCFA pool were reduced linearly $(P=0.003$ and $P<$ 0.001 respectively) by inclusion of increasing doses of GG and SA in the diet. In contrast, there were no significant between-diet effects on the molar proportions of isovalerate.

\section{Plasma cholesterol concentrations and output of faecal bile acids}

Plasma total cholesterol concentration fell linearly $(P=0.03$; Fig. 2(a)) with increasing NSP in the diet and the effect was similar for both GG and SA. Output of total bile acids during the balance period rose from $24 \mu \mathrm{mol} / 7 \mathrm{~d}$

Table 3. Rat weight, small intestine length, caecal and colonic organ mass, caecal and colonic tissue weights for rats given semi-purified diets supplemented with 50 and $100 \mathrm{~g}$ guar gum/kg (5\% GG and $10 \%$ GA respectively) or 50 and $100 \mathrm{~g}$ sodium alginate/kg (5 \% SA and $10 \%$ SA respectively)*

(Means for five rats per diet, except $10 \%$ SA where values are for three rats per diet)

\begin{tabular}{|c|c|c|c|c|c|c|c|c|c|c|}
\hline \multirow[b]{2}{*}{ Diet... } & \multirow[b]{2}{*}{ Control } & \multirow[b]{2}{*}{$5 \%$ GG } & \multirow[b]{2}{*}{$10 \% \mathrm{GG}$} & \multirow[b]{2}{*}{$5 \%$ SA } & \multirow[b]{2}{*}{$10 \% \mathrm{SA}$} & \multirow[b]{2}{*}{ SEM } & \multicolumn{4}{|c|}{ Statistical significance of contrast ${ }^{\dagger}(P)$ : } \\
\hline & & & & & & & 1 & 2 & 3 & 4 \\
\hline Small intestine length (cm) & 107 & 129 & 124 & 121 & 123 & $2 \cdot 1$ & 0.002 & 0.003 & 0.96 & 0.08 \\
\hline \multicolumn{11}{|l|}{ Caecum } \\
\hline Total mass $(\mathrm{g})$ & $2 \cdot 30$ & $4 \cdot 11$ & $5 \cdot 56$ & 4.67 & $5 \cdot 75$ & $0 \cdot 314$ & $<0.001$ & 0.29 & 0.78 & 0.35 \\
\hline Tissue mass $(\mathrm{g})$ & 0.53 & 0.85 & 1.02 & 0.78 & 1.01 & 0.044 & $<0.001$ & 0.46 & 0.85 & 0.41 \\
\hline Digesta mass (g) & $1 \cdot 77$ & $3 \cdot 26$ & 4.53 & 3.88 & $4 \cdot 74$ & $0 \cdot 274$ & $<0.001$ & 0.29 & 0.74 & 0.25 \\
\hline \multicolumn{11}{|l|}{ Colon } \\
\hline Total mass $(\mathrm{g})$ & 2.02 & 3.07 & 2.93 & $3 \cdot 37$ & $3 \cdot 45$ & 0.143 & 0.002 & 0.006 & 0.16 & 0.35 \\
\hline Tissue mass $(\mathrm{g})$ & 0.96 & $1 \cdot 13$ & $1 \cdot 24$ & $1 \cdot 14$ & $1 \cdot 28$ & 0.046 & 0.03 & 0.75 & 0.78 & 0.96 \\
\hline Digesta mass (g) & 1.06 & 1.94 & 1.69 & 2.35 & $2 \cdot 18$ & 0.116 & 0.004 & 0.001 & 0.09 & 0.23 \\
\hline
\end{tabular}

* For details of diets and procedures, see Table 1 and p. 318.

$\dagger$ Contrast 1 , linear (L) effect of added NSP; contrast 2 , deviations from linear (D) effect of added NSP; contrast $3, \mathrm{~L} \times$ NSP source interaction; contrast 4 , D $\times$ NSP source interaction. 
Table 4. $\mathrm{pH}$, total short-chain fatty acid (SCFA) concentration ( $\mu \mathrm{mol} / \mathrm{g}$ caecal contents) and molar proportions ( $\mu \mathrm{mol} / 100 \mu \mathrm{mol})$ of individual SCFA in the caeca of rats given semi-purified diets' supplemented with 50 and 100 g guar gum $/ \mathrm{kg} \mathrm{(5 \%} \mathrm{GG} \mathrm{and} 10 \%$ GG respectively) or 50 and $100 \mathrm{~g}$ sodium alginate (5\% SA and $10 \%$ SA respectively) ${ }^{\star}$

(Means for five rats per diet, except $10 \%$ SA where values are for three rats per group)

\begin{tabular}{|c|c|c|c|c|c|c|c|c|c|c|}
\hline \multirow[b]{2}{*}{ Diet... } & \multirow[b]{2}{*}{ Control } & \multirow[b]{2}{*}{$5 \%$ GG } & \multirow[b]{2}{*}{$10 \%$ GG } & \multirow[b]{2}{*}{$5 \%$ SA } & \multirow[b]{2}{*}{$10 \% \mathrm{SA}$} & \multirow[b]{2}{*}{ SEM } & \multicolumn{4}{|c|}{ Statistical significance of contrast $^{\dagger}(P)$ : } \\
\hline & & & & & & & 1 & 2 & 3 & 4 \\
\hline Caecal pH & $6 \cdot 6$ & $6 \cdot 3$ & $6 \cdot 1$ & $6 \cdot 8$ & $6 \cdot 7$ & 0.06 & 0.002 & 0.003 & 0.96 & 0.08 \\
\hline Total SCFA ( $\mu \mathrm{mol} / \mathrm{g}$ caecal content) & 79 & 102 & 106 & 62 & 70 & $4 \cdot 28$ & 0.07 & 0.46 & 0.001 & $<0.001$ \\
\hline \multicolumn{11}{|c|}{ Molar proportions of individual SCFA } \\
\hline Acetate & $64 \cdot 1$ & $61 \cdot 4$ & $68 \cdot 3$ & $71 \cdot 0$ & $71 \cdot 7$ & 1.39 & $0 \cdot 10$ & 0.81 & 0.43 & 0.02 \\
\hline Propionate & 19.9 & 17.5 & 18.5 & $16 \cdot 2$ & $15 \cdot 1$ & 0.79 & 0.30 & 0.29 & 0.23 & 0.58 \\
\hline Isobutyrate & 1.7 & $1 \cdot 2$ & 0.6 & 0.8 & 1.0 & 0.12 & 0.003 & 0.32 & 0.19 & 0.28 \\
\hline Butyrate & $10 \cdot 9$ & 17.4 & $10 \cdot 2$ & $9 \cdot 5$ & $9 \cdot 7$ & 1.10 & 0.55 & 0.15 & 0.89 & 0.02 \\
\hline Isovalerate & 1.8 & 1.5 & 1.8 & 1.4 & 1.7 & 0.10 & 0.98 & 0.15 & 0.84 & 0.88 \\
\hline Valerate & 1.6 & 1.0 & 0.7 & 1.0 & 0.8 & 0.09 & $<0.001$ & 0.30 & 0.60 & 0.76 \\
\hline
\end{tabular}

${ }^{*}$ For details of diets and procedures, see Table 1 and p. 318.

† Contrast 1, linear (L) effect of added NSP; contrast 2, deviations from linear (D) effect of added NSP; contrast 3, L $\times$ NSP source interaction; contrast 4, D $\times$ NSP source interaction.

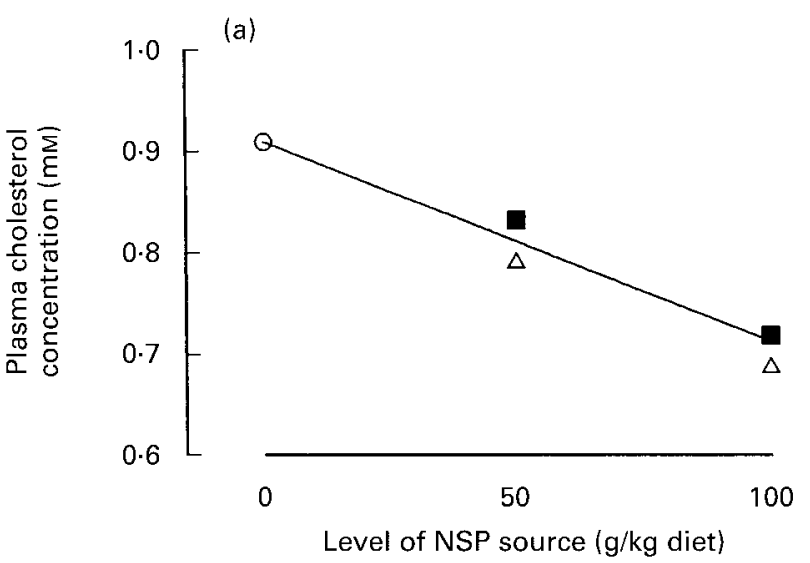

(b)

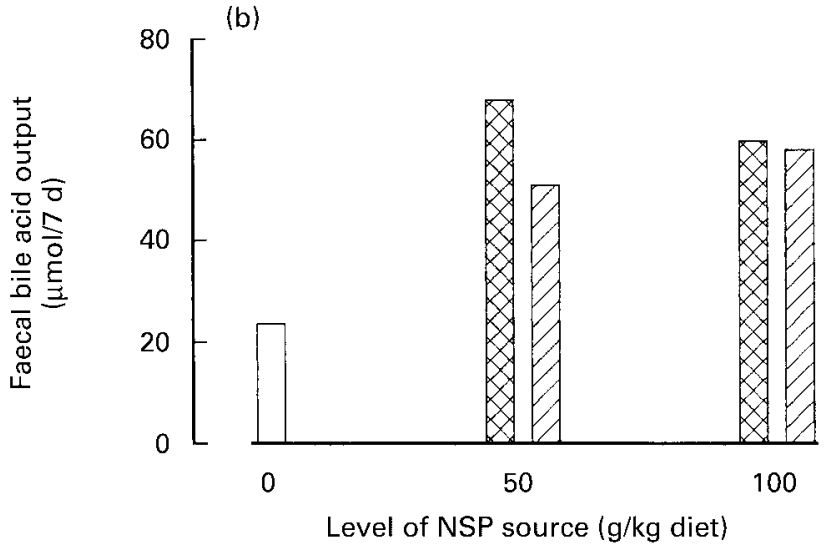

Fig. 2. (a) Concentrations of total cholesterol in plasma from rats fed semi-purified diets supplemented with 50 and $100 \mathrm{~g}$ guar gum $/ \mathrm{kg}(\mathbf{\square})$ or 50 and $100 \mathrm{~g}$ sodium alginate/kg $(\triangle),(\bigcirc)$, Control diet. For details of diets and procedures, see Table 1 and p. 318. Values are means for five rats per diet except $100 \mathrm{~g}$ sodium alginate $/ \mathrm{kg}$ where there were three rats per diet. There was a significant $(P=0.03)$ linear effect of level of added NSP. The pooled SEM for an individual diet group was $0.038 \mathrm{~mm}$. (b) Faecal bile acid output of the rats during the balance period. (ख), Guar gum; (『), sodium alginate; ( $\square$ ), Control diet. There were significant linear $(P=0.003)$ and deviations-fromlinear $(P=0.02)$ effects of the level of added NSP. The pooled SEM for an individual diet group was $4.63 \mu \mathrm{mol} / 7 \mathrm{~d}$. in control rats to a mean of $59 \mu \mathrm{mol} / 7 \mathrm{~d}$ in rats fed $5 \% \mathrm{GG}$ and $5 \%$ SA diets respectively, with no further increase with the higher inclusion rate (Fig. 2(b)).

\section{Discussion}

\section{Fate of NSP sources in the gut}

In rats fed $5 \% \mathrm{GG}$ and $5 \% \mathrm{SA}$ diets, $0.9-1.0$ of the additional NSP was digested, confirming the high overall digestibility of these soluble NSP. Similar calculations for the $100 \mathrm{~g} / \mathrm{kg}$ inclusion rate, however, show that digestibility of the additional NSP source was significantly reduced $(P<0.001)$ and approximately 0.2 of the additional NSP had not been digested, implying that at the higher inclusion rate the capacity for near complete digestion of the NSP had been exceeded. Approximately $100 \%$ disappearance of guar gum within the alimentary tracts of rats and human subjects has been reported (Nyman et al. 1986), but to our knowledge the present study is the first study that has attempted to determine the effect of an oral dose of guar gum (or sodium alginate) on digestibility of the NSP in the hydrocolloid. In contrast to earlier studies in which peas (Pisum sativum); bread and beans (Phaseolus vulgaris) were fed to rats at a range of doses and where there was little evidence of a diminution in digestibility of NSP with higher intakes (Goodlad \& Mathers, 1990, 1992; Key \& Mathers, 1993a,b, 1995), the present study provided clear evidence that with $100 \mathrm{~g}$ NSP source $/ \mathrm{kg}$ diet, there was significantly $(P<0.001)$ reduced whole-gut NSP digestibility (Fig. 1).

Most algal polysaccharides are resistant to digestion by digestive enzymes, and almost all uronic acids derived from sodium alginate consumed by ileostomy patients could be recovered in ileostomy fluid (Sandberg et al. 1994). In vitro fermentation of alginates using human faecal flora (Michel et al. 1996) showed that approximately $83 \%$ of the fibre disappeared, but only $57 \%$ was metabolised to SCFA, resulting in a small change in $\mathrm{pH}$ of the incubation medium. Michel et al. (1996) concluded that the disappearance of uronic acids was due to the 
involvement of 'an unusual and unknown' fermentative pathway resulting in approximately $40 \%$ of the disappeared material being metabolised through pathways other than SCFA and gas production. It is possible that all, or virtually all, the NSP that disappeared within the intestines of the rats fed GG and SA in the present study did so by bacterial degradation within the large bowel. The reason for the reduced NSP digestibility with the higher NSP intake was not established, but may be associated with inadequate time for bacterial hydrolysis of the test polymers, since alterations in gut transit time has a strong influence on extent of NSP digestion (Mathers, 1991).

There was a strong linear increase in faecal $\mathrm{N}$ output with increasing consumption of GG and SA, which is consistent with previous observations in rats fed increasing levels of dietary NSP (for example, see Goodlad \& Mathers, 1990; Key \& Mathers, 1993a). It has been suggested that increased faecal $\mathrm{N}$ output may be due to enhanced loss of endogenous $\mathrm{N}$ arising from stimulation of mucosal cell turnover (Skurpakkar et al. 1979). Although tissue hypertrophy was observed in the present experiment with both NSP sources, no measurements of intestinal mucosal cell proliferation were made. Fairweather Tait et al. (1983) have demonstrated that, although faecal $\mathrm{N}$ loss was increased in bean-fed rats, this loss could not be attributed to increased cell turnover. An alternative source of faecal $\mathrm{N}$ is bacterial $\mathrm{N}$, which may be elevated in response to increased supply of fermentable organic matter to the caecal or colonic bacteria (Mason \& Palmer, 1973; Goodlad \& Mathers, 1990, 1992; Key \& Mathers, 1993b). Fermentation of supplemental GG and SA would be expected to increase bacterial cell growth in the large bowel (Key \& Mathers, 1995) and to elevate bacterial N output in faeces.

\section{Hypocholesterolaemic effects of NSP sources}

Many studies with human volunteers have investigated the hypocholesterolaemic effects of NSP from a variety of sources including oats, psyllium, pectin and guar gum. A recent meta-analysis of data from sixty-seven controlled trials (Brown et al. 1999) concluded that the cholesterollowering effects of oats, psyllium and pectin were similar. The authors were unable to compare the effects of GG, owing to the limited number of studies available in which GG intakes were similar to those of the other NSP. Whilst the effects of the NSP were significant, they were considered small $(-0.045 \mathrm{mmol} / \mathrm{l}$ per $\mathrm{g}$ 'soluble fibre') within the 'practical' range of NSP intake $(2-10 \mathrm{~g} / \mathrm{d})$. The data from animal studies, using a variety of laboratory rodents and larger animals, have also shown consistently that soluble NSP have a strong cholesterol-lowering effect, although the majority of these studies have included NSP at levels that could not be achieved readily in Western diets, and differences in lipid metabolism between species mean that direct comparison with human subjects should be made with some caution. In the present study there was a similar linear decrease in plasma total cholesterol concentration with both NSP sources with, on average, a $14 \%$ reduction in cholesterol concentration for the higher dose of the two NSP sources compared with control rats. This reduction in plasma cholesterol concentration was achieved despite feeding cholesterol-free diets, and must therefore reflect changes in endogenous cholesterol metabolism.

The mechanisms by which NSP, which form viscous aqueous solutions, exert their hypocholesterolaemic effects remain unclear. The NSP may exert direct physicochemical effects within the small intestine which interfere with formation and diffusion of bile acid and cholesterolcontaining micelles through the viscous matrix of the digesta. This immobilization may result in reduced absorption of cholesterol and bile acids (Gallaher et al. 1993; Carr et al. 1996) causing an interruption in the entero-hepatic circulation of cholesterol and its metabolites. The resulting decrease in the cholesterol content of liver cells leads to an up regulation of LDL receptors and thus increased clearance of LDL-cholesterol from the blood (Fernandez, 1995). Changes in the activity of cholesterol $7 \alpha$-hydroxylase has also been reported in rats fed soluble NSP (Buhman et al. 1998) or cholestyramine, a bile acid sequestrant (Chiang et al. 1990). The increased faecal excretion of total bile acids observed in rats fed GG and SA (Fig. 2(b)) is consistent with studies in laboratory rats fed cholesterol-free diets supplemented with a range of soluble NSP including GG at similar inclusion rates to those used in the present study (Gallaher et al. 1992; Overton et al. 1994; Moundras et al. 1997; Buhman et al. 1998). Studies in animals fed cholesterol-containing diets (for example, see Trautwein et al. 1998, 1999), and in human subjects fed normal diets (Jenkins et al. 1980; Bosaeus et al. 1986), have also reported increased faecal bile acid excretion following consumption of soluble NSP. Approximately a twofold increase in neutral sterol output (not determined in the present experiment) has been observed in rats fed cholesterol-free diets containing $75 \mathrm{~g}$ GG/kg (Moundras et al. 1997) and $50 \mathrm{~g}$ psyllium husk $/ \mathrm{kg}$ (Buhman et al. 1998), and a similar increase in endogenous sterol loss may also contribute to the cholesterol-lowering effect of both GG and SA observed in the present experiment. There are variable responses to different NSP sources (Story et al. 1997), with some NSP (e.g. oat bran and psyllium) causing a much greater increase in faecal bile acid output than other sources (e.g. barley bran). Conflicting results on the effects of alginates between laboratory animals and human subjects have been reported. For example, Sandberg et al. (1994) found that bile acid excretion was reduced in ileostomy patients consuming sodium alginate, whereas Wu \& Peng (1997) reported that faecal bile acid output was increased in rats fed diets containing $50 \mathrm{~g}$ alginate $/ \mathrm{kg}$. The differences between responses in human subjects and laboratory animals may be due to the higher levels of NSP intake used in the latter which are not achievable in human subjects, and to differences in lipid metabolism between species. In the present experiment the effects of GG and SA were similar, with a two- to threefold increase in faecal bile acid output compared with control rats. This increase was observed at the $50 \mathrm{~g} / \mathrm{kg}$ level of added NSP source, but did not increase further when the NSP source was added at $100 \mathrm{~g} / \mathrm{kg}$ of the test diets, despite the fact that the linear fall in plasma cholesterol concentration continued to the NSP source inclusion level of $100 \mathrm{~g} / \mathrm{kg}$. This finding suggests that, while the interruption in the entero-hepatic circulation of bile acids may be important in reducing 
plasma cholesterol concentration at lower intakes of the test NSP sources, another explanation must be sought for the additional fall in plasma cholesterol concentration between 50 and $100 \mathrm{~g}$ NSP source $/ \mathrm{kg}$ diet.

\section{Is increased caecal propionate responsible for cholesterol lowering?}

Since altered sterol absorption does not provide an adequate explanation for the hypercholesterolaemic effects of viscous NSP sources, alternative mechanisms have been sought. Anderson (1985) suggested that increased hepatic propionate supply via the portal vein from large-bowel NSP fermentation may inhibit hydroxymethylglutaryl-CoA reductase, the rate-limiting enzyme for cholesterol biosynthesis (Rodwell et al. 1976; Levrat et al. 1994), and thus reduce circulating cholesterol concentrations. There is no doubt that increased consumption of fermentable NSP has been associated with increased caecal production of SCFA, and higher concentrations of SCFA, including propionate, in portal blood (Goodlad \& Mathers, 1990). However, the reported effects of increased propionate availability on blood cholesterol concentrations or on hepatic cholesterol synthesis rate are not consistent (Chen et al. 1984; Illman et al. 1988; Venter et al. 1990; Todesco et al. 1991; Beaulieu \& McBurney, 1992; Demigné et al. 1995; Lin et al. 1995; Hara et al. 1998). This apparent inconsistency, coupled with apparent variations in response between human and rat hepatocytes in vitro (Lin et al. 1995), casts some doubt on the primary role of propionate in reducing plasma cholesterol concentrations. In rats fed GG caecal propionate concentrations were higher than those for both control $(P=0.13)$ and SA-fed $(P=0.01)$ rats $(18.7 \mathrm{mM}$ $v$. 15.7 and $10.2 \mathrm{mM}$ respectively) and this increase propionate would be expected to result in increased portal appearance of the SCFA (Goodlad \& Mathers, 1990). However, in animals fed SA caecal propionate concentrations were approximately 0.66 of those in control rats and 0.55 of those in GG-fed rats. Although data on hepatic supply of propionate are not available, it seems unlikely that the hypocholesterolaemia observed in SA-fed rats was due to the effects of propionate on hepatic cholesterol synthesis.

\section{Conclusion}

The results presented here show that SA has a strong hypocholesterolaemic effect in rats (equivalent to that of GG) and that this response is most probably mediated through an interruption in the entero-hepatic circulation of cholesterol and bile acids, and not through fermentation of the NSP to produce additional propionate in the large intestine. This finding suggests that the NSP may have potential for use as a dietary supplement in human subjects at risk of developing hypercholesterolaemia.

\section{Acknowledgements}

The authors are grateful to Shirley Middleton and Anne Sanderson for their technical assistance in the analysis of samples, and to staff in the Comparative Biology Centre,
University of Newcastle for the care and maintenance of laboratory animals. The sodium alginate was kindly donated by Serge Mabeau, CEVA, Pleubian, France, through the EC AIR Programme (AIR ICT 92-0518).

\section{References}

Anderson JW (1985) Physiological and metabolic effects of dietary fibre. Federation Proceedings 44, 2902-2906.

Beaulieu KE \& McBurney MI (1992) Changes in pig serum lipids, nutrient digestibility and sterol excretion during cecal infusion of propionate. Journal of Nutrition 122, 241-245.

BeMiller JN \& Whistler RL (1996) Carbohydrates. In Food Chemistry, 3rd ed., pp. 157-223 [OM Fennema, editor]. New York: Marcel Dekker.

Bosaeus I, Carlsson N-G, Sandberg A-S \& Andersson H (1986) Effect of wheat bran and pectin on bile acid and cholesterol excretion in ileostomy patients. Human Nutrition Clinical Nutrition 40, 429-440.

Brown L, Willett WW \& Sacks FM (1999) Cholesterol-lowering effects of dietary fiber: a meta-analysis. American Journal of Clinical Nutrition 69, 30-42.

Buhman KK, Furumoto EJ, Donkin SS \& Story JA (1998) Dietary psyllium increases fecal bile acid excretion, total steroid excretion and bile acid biosynthesis in rats. Journal of Nutrition 128, 1199-1203.

Carr TP, Gallaher DD, Yang C-H \& Hassel CA (1996) Increased intestinal contents viscosity reduces cholesterol absorption efficiency in hamsters fed hydroxypropyl methylcellulose. Journal of Nutrition 126, 1463-1469.

Chen WL, Anderson JW \& Jennings D (1984) Propionate may mediate the hypocholesterolemic effect of certain soluble plant fibres in cholesterol fed rats. Proceedings of the Society for Experimental Biology and Medicine 175, 215-218.

Chiang JYL, Miller WF \& Lin G-M (1990) Regulation of cholesterol $7 \alpha$-hydroxylase and the immunological evidence for the induction of cholesterol $7 \alpha$-hydroxylase by cholestyramine and circadian rhythm. Journal of Biological Chemistry 265, 3889-3897.

Demigné C, Morand C, Levrat M-A, Besson C, Moundras C \& Rémésy C (1995) Effect of propionate on fatty acid and cholesterol synthesis and on acetate metabolism in isolated rat hepatocytes. British Journal of Nutrition 74, 209-219.

Englyst HN \& Cummings JH (1984) Simplified method for the measurement of total non-starch polysaccharides by gas-liquid chromatography of constituent sugars as the alditol acetates. Analyst 109, 937-942.

Fairweather Tait SJ, Gee JM \& Johnson IT (1983) The influence of cooked kidney beans (Phaseolus vulgaris) on intestinal cell turnover and faecal nitrogen excretion in the rat. British Journal of Nutrition 49, 303-312.

Fernandez ML (1995) Distinct mechanisms of plasma LDL lowering by dietary fibre in the guinea pig: specific effects of pectin, guar gum and psyllium. Journal of Lipid Research 36, 2394-2404.

Frape DL \& Jones AM (1995) Chronic and postprandial responses of plasma insulin, glucose and lipids in volunteers given dietary fibre supplements. British Journal of Nutrition 73, 733-751.

Gallaher DD, Hassel CA, Lee K-J \& Gallaher CM (1993) Viscosity and fermentability as attributes of dietary fiber responsible for the hypocholesterolemic effect in hamsters. Journal of Nutrition 123, 244-252.

Gallaher DD, Locket PL \& Gallaher CM (1992) Bile acid metabolism in rats fed two levels of corn oil and brans of oat, rye and barley and sugar beet fiber. Journal of Nutrition 122, 473-481.

Goodlad JS \& Mathers JC (1990) Large bowel fermentation in rats 
given diets containing raw peas (Pisum sativum). British Journal of Nutrition 64, 569-587.

Goodlad JS \& Mathers JC (1992) Digestion of complex carbohydrates and large bowel fermentation in rats fed on raw and cooked peas (Pisum sativum). British Journal of Nutrition 67, 475-488.

Hara H, Haga S, Aoyama Y \& Kiriyama S (1998) Short-chain fatty acids suppress cholesterol synthesis in rat liver and intestine. Journal of Nutrition 129, 942-948.

Illman RJ, Topping DL, McIntosh GH, Trimble RP, Storer GB, Taylor MN \& Cheng BQ (1988) Hypocholesterolemic effects of dietary propionate; studies in whole animals and perfused rat liver. Annals of Nutrition and Metabolism 32, 97-107.

Jenkins DJA, Reynolds D, Slavin B, Leeds AR, Jenkins AL \& Jepson EH (1980) Dietary fiber and blood lipids: treatment of hypocholesterolaemia with guar crispbread. American Journal of Clinical Nutrition 33, 575-581.

Key FB \& Mathers JC (1993a) Gastrointestinal responses of rats fed on white and wholemeal breads: complex carbohydrate digestibility and the influence of dietary fat content. British Journal of Nutrition 69, 481-495.

Key FB \& Mathers JC (1993b) Complex carbohydrate digestion and large bowel fermentation in rats given wholemeal bread and cooked haricot beans (Phaseolus vulgaris) fed in mixed diets. British Journal of Nutrition 69, 497-509.

Key FB \& Mathers JC (1995) Digestive adaptations of rats given white bread and cooked haricot beans (Phaseolus vulgaris): large bowel fermentation and digestion of complex carbohydrates. British Journal of Nutrition 74, 393-406.

Levrat M-A, Favier M-L, Moundras C, Rémésy C, Demigné C \& Morand C (1994) Role of dietary propionic acid and bile acid excretion in the hypocholesterolemic effects of oligosaccharides in rats. Journal of Nutrition 124, 531-538.

Lin Y, Vonk RJ, Sloof MJH, Kuipers F \& Smit MJ (1995) Differences in propionate-induced inhibition of cholesterol and triacylglycerol synthesis between human and rat hepatocytes in primary culture. British Journal of Nutrition 74, 197-207.

Martin G (1986) Evaluation toxilogique et nutritionelle des alginates. Définition, structure, fabrication propiétés et applications (Toxicological and nutritional evaluation of alginates, Definition, structure, manufacturing properties and applications). Science Aliments 6, 473-486.

Mason VC \& Palmer R (1973) The influence of bacterial activity in the alimentary canal of rats on faecal nitrogen excretion. Acta Agriculturae Scandinavica 23, 141-150.

Mathers JC (1991) Digestion on non-starch polysaccharides by non-ruminant omnivores. Proceedings of the Nutrition Society 50, 161-172.

Mathers JC, Fernandez F, Hill MJ, McCarthy PT, Shearer MJ \& Oxley A (1990) Dietary modification of potential vitamin K supply from enteric bacteria menaquinones in rats. British Journal of Nutrition 63, 639-652.

Michel C, Lahaye M, Bonnet C, Mabeau S \& Barry JL (1996) In vitro fermentation by human faecal bacteria of total and purified dietary fibres from brown seaweeds. British Journal of Nutrition 75, 263-280.

Michel C \& Macfarlane GT (1996) Digestive fates of soluble polysaccharides from marine macroalgae: involvement of the colonic microflora and physiological consequences for the host. Journal of Applied Bacteriology 80, 349-369.

Morgan LM, Tredger JA, Shavila Y, Travis JS \& Wright J (1993) The effect of non-starch polysaccharide supplementation on circulating bile acids, hormone and metabolite levels following a fat meal in human subjects. British Journal of Nutrition 70, 491-501.

Moundras C, Behr SR, Rémésy C \& Demigné C (1997) Fecal losses of sterols and bile acids induced by feeding rats guar gum are due to greater pool size and liver bile acid secretion. Journal of Nutrition 127, 1068-1076.

Nyman M, Asp N-G, Cummings J \& Wiggins H (1986) Fermentation of dietary fibre in the intestinal tract: comparison between man and rat. British Journal of Nutrition 55, 487-496.

Overton PD, Furlonger N, Beety JM, Chakraborty J, Tredger JA \& Morgan IM (1994) The effects of dietary sugar-beet fibre and guar gum on lipid metabolism in Wistar rats. British Journal of Nutrition 72, 385-395.

Rodwell VW, Nordstrom JL \& Mitschelen JJ (1976) Regulation of HMG-CoA reductase. Advances in Lipid Research 14, 1-74.

Roper CS, Bal W \& Mathers JC (1996) Comparison of two algal polysaccharides with guar gum and cellulose on bowel habit in healthy human volunteers. Proceedings of the Nutrition Society 55, 238A.

Sandberg AS, Andersson H, Bosaeus I, Carlsson NG, Hasselblad K \& Harrod M (1994) Alginate, small bowel sterol excretion, and absorption of nutrients in ileostomy subjects. American Journal of Clinical Nutrition 60, 751-756.

Seal CJ \& Mathers JC (1996) Comparative gastrointestinal responses to guar gum and a seaweed polysaccharide (sodium alginate) in rats. Proceedings of the Nutrition Society 55, 55A.

Setchell KDR, Lawson AM, Tamida N \& Sjövall J (1983) General methods for the analysis of metabolic profiles of bile acids and related compounds in faeces. Journal of Lipid Research 24, $1085-1100$

Skurpakkar KS, Sundaravalli OE \& Rao MN (1979) In vitro and in vivo digestibility of legume carbohydrates. Nutrition Reports International 19, 111-117.

Story JA, Furumoto EJ \& Buhman KK (1997) Dietary fiber and bile acid metabolism - an update. In Dietary Fibre in Health and Disease, pp. 259-266 [D Krichevsky and C Bonfield, editors]. New York: Plenum Press.

Todesco T, Rao AV, Bosello O \& Jenkins DJA (1991) Propionate lowers blood glucose and alters lipid metabolism in health subjects. American Journal of Clinical Nutrition 54, 860-869.

Trautwein EA, Kunath-Rau A \& Erbersdober HF (1998) Effect of different varieties of pectin and guar gum on plasma, hepatic and biliary lipids and cholesterol gallstone formation in hamsters fed on high-cholesterol diets. British Journal of Nutrition 79, 463-471.

Trautwein EA, Kunath-Rau A \& Erbersdobler HF (1999) Increased fecal bile acid excretion and changes in the circulating bile acid pool are involved in the hypocholesterolemic and gallstone-preventive actions of psyllium in hamsters. Journal of Nutrition 129, 896-902.

Tredger JA, Morgan LM, Travis J \& Marks V (1991) The effects of guar gum, sugar beet fibre and wheat bran supplementation on serum lipoprotein levels in normocholesterolaemic volunteers. Journal of Human Nutrition and Dietetics 4, 375-384.

Truswell AS (1995) Dietary fibre and plasma lipids. European Journal of Clinical Nutrition 49, S105-S109.

Venter CS, Vorster HH \& Cummings JH (1990) Effects of dietary propionate on carbohydrate and lipid metabolism in healthy volunteers. American Journal of Gastroenterology 85, 549-553.

Wu J \& Peng SS (1997) Comparison of hypolipidemic effect of refined konjac meal with several common dietary fibers and their mechanisms of action. Biomedical and Environmental Sciences 10, 27-37. 